\title{
The Overlooked Hybrid: Geographic Distribution and Niche Differentiation Between Spartina Cytotypes (Poaceae) in Wadden Sea Salt Marshes
}

\author{
Dirk Granse $^{1}$ D . Mariana Romeiro Motta ${ }^{2} \cdot$ Sigrid Suchrow $^{1} \cdot$ Klaus von Schwartzenberg $^{3} \cdot$ Arp Schnittger $^{2}$. \\ Kai Jensen ${ }^{1}$
}

Received: 9 September 2020 / Revised: 9 April 2021 / Accepted: 19 July 2021 / Published online: 12 October 2021

(C) The Author(s) 2021, corrected publication 2022

\begin{abstract}
Whole genome duplications (WGDs) lead to polyploid specimens and are regarded as major drivers for speciation and diversification in plants. One prevalent problem when studying WGDs is that effects of polyploidization in ancient polyploids cannot be disentangled from the consequences of selective evolutionary forces. Cytotypic differences in distribution, phenotypic appearance and in response to surface elevation (determined by HOF-modeling) were identified in a relatively young taxa-group of a hexaploid $\mathrm{F}_{1}$-hybrid (Spartina $\times$ townsendii $\mathrm{H}$. Groves \& J. Groves, Poaceae) and its dodecaploid descendent (Spartina anglica C.E. Hubbard, Poaceae) using vegetation assessments $\left(1029\right.$ plots; $\left.1 \times 1 \mathrm{~m}^{2}\right)$ from the European Wadden Sea mainland salt marshes, including elevational and mean high tidal (MHT) data. While the $\mathrm{F}_{1}{ }^{-}$ hybrid was mainly present in the eastern part of the Wadden Sea, its dodecaploid descendent occurred in the entire Wadden Sea area. The Spartina cytotypes differed in phenotypes (median of Spartina cover: hexaploid $=25 \%$ vs. dodecaploid $=$ $12 \%$ ) and in elevational niche-optimum (hexaploid $=-49.5 \mathrm{~cm}$ MHT vs. dodecaploid $=8.0 \mathrm{~cm}$ MHT). High ploidy levels correlated with establishment success in Spartina along geographic gradients but did not seem to increase the capacity to cope with abiotic severity downwards the elevational gradient in salt marshes.
\end{abstract}

Keywords Allopolyploidy · Sporobolus · Whole genome duplication (WGD) · Niche differentiation ·

Elevational gradient $\cdot$ HOF modeling

\section{Introduction}

Whole genome duplication (WGD; or polyploidization) is a key mechanism in plant evolution (Soltis et al. 2014; Soltis and Soltis 2016; Čertner et al. 2017) with profound consequences for plant ecology (e.g., Sonnleitner et al. 2015; Barker et al. 2016a, b, Segraves

Communicated by: R. Scott Warren

Dirk Granse

dirk.granse@uni-hamburg.de

1 Applied Plant Ecology, Institute of Plant Science and Microbiology, Universität Hamburg, Hamburg, Germany

2 Developmental Biology, Institute of Plant Science and Microbiology, Universität Hamburg, Hamburg, Germany

3 Aquatic Ecophysiology and Phycology, Institute of Plant Science and Microbiology, Universität Hamburg, Hamburg, Germany and Anneberg 2016). WGD can alter plant physiology, development, and growth (cf. Wendel 2000; Leitch and Leitch 2008; Birchler 2012; Laport et al. 2016). Therefore, it may increase the capacity of polyploids to establish in recently deglaciated areas (cf. Ehrendorfer 1980; Theodoridis et al. 2013; Novikova et al. 2018) and at high latitudes (Brochmann et al. 2004; Rice et al. 2019). Moreover, these WGD-related alterations may explain differences between polyploids and their progenitors in the range along climate-related gradients, such as temperature, precipitation conditions, or altitude above sealevel (e.g., Theodoridis et al. 2013; Marchant et al. 2016; Wefferling et al. 2017). WGD may also increase the capacity of polyploids to live under increased abiotic severity, such as anoxia, salinity, or pollution (cf. Maherali et al. 2009; Godfree et al. 2017; Cavé-Radet et al. 2019).

Naturally formed polyploids live in sympatry with their progenitors and have immediately to overcome reproductive disadvantages, such as minority cytotype exclusion (Levin 1975) or genomic changes generated by homoeologous 
recombination (Gaeta and Pires 2010). Polyploidization can aid to overcome hybrid infertility (Birchler 2012; Charron et al. 2019; Meeus et al. 2020) and hybridization barriers by enabling gene flow between reproductively isolated parental taxa (Lafon-Placette et al. 2017; Marburger et al. 2019). However, being inherently different from their progenitors in the capacity to cope with environmental factors may help neopolyploids to escape from the sympatric niche.

For ancient polyploids, the effects of former WGD cannot be distinguished from effects of subsequent evolution (Soltis et al. 2016). Therefore, studying neopolyploids opens the possibility to disentangle the effects of selective evolution from WGD on niche differentiation. For example, Maherali et al. (2009) concluded by comparing extant di- and tetraploid with experimentally synthesized neotetraploid Chamerion angustifolium that tetraploids developed the enhanced ability to survive water stress after polyploidization. In addition, Ramsey (2011) compared tetra-, hexa-, and neohexaploid Achillea borealis and concluded that the hexaploid A. borealis had achieved the ability to adapt to a novel environment particularly through polyploidization. In our study, we aim to investigate the effects of WGD in the genus of Spartina, a well-established model system for studying recent $(<200$ years) hybridization and WGD (e.g., Ferreira de Carvalho et al. 2017; Chelaifa et al. 2010; Ainouche et al. 2012), by focusing on the establishment success along geographic and abiotic gradients.

Spartina anglica C.E. Hubbard (dodecaploid cytotype) evolved by WGD from the $\mathrm{F}_{1}$-hybrid Spartina $\times$ townsendii H. Groves \& J. Groves (hexaploid cytotype; Marchant 1968; Baumel et al. 2003; Ainouche et al. 2003) in the second half of the nineteenth century in Britain (Marchant 1967). Spartina $\times$ townsendii in turn emerged from hybridization of Spartina alterniflora Loiseleur and Spartina maritima (Curtis) Fernald. All these taxa belong to a monophyletic lineage of Spartina, recently included in the genus Sporobolus (Peterson et al. 2014). Spartina has been the subject of various research disciplines, e.g., in ecology, biogeography, and molecular biology (reviewed in Bortolus et al. 2019). However, only a few studies have been dealing with direct comparisons of Spartina cytotypes (e.g., Hubbard 1969; Raybould 2005; Proença et al. 2019), and so far, detailed studies with respect to geographic distributions and ecological niches of the cytotypes are lacking.

The cytotypes Spartina $\times$ townsendii and Spartina anglica differ in their reproductive and associated dispersal capacities. While the hexaploid cytotype is mostly capable of vegetative spreading, the dodecaploid cytotype regained fertility with WGD and spreads vegetatively as well as by seeds (cf. Marchant 1968; Hubbard 1970; Marks and Truscott 1985). Recent publications reported that the hexa- and dodecaploid cytotypes co-occur (Drok 1983; Partridge 1987; Vinther et al. 2001; Michaelis 2008; Saarela 2012; Huska et al. 2016; Wong et al. 2018). However, a systematic understanding of the distribution of Spartina $\times$ townsendii and Spartina anglica in salt marshes is missing (cf. Raybould 2005).

The globally most important habitat of Spartina cytotypes are salt marshes. These ecosystems develop along sheltered coastlines under tidal inundations. With increasing duration and frequency of flooding along the decreasing elevation in salt marshes, severity of anoxic conditions increases (Colmer and Flowers 2008; Bakker et al. 2020; Mueller et al. 2020). Another abiotic stressor of plant growth in salt marshes is increased salinity. Usually, salinity in salt marshes reflects salinity of the neighboring water body (e.g., de Leeuw et al. 1991). It is, however, also affected by single precipitation events, extraordinary heat waves (cf. Strain et al. 2017; Wong et al. 2018), and regular annual summer droughts (cf. Schröder et al. 2002). Along the elevational salt marsh gradient, vegetation often shows distinct zones resulting from the interplay of plant adaptations to abiotic stress (mainly anoxia and salinity; Suchrow et al. 2015) and competitive interactions among plants (Adam 1993; Suchrow and Jensen 2010; Engels et al. 2011). Thus, ecological advantages of WGD could be reflected by an increased capacity of the dodecaploid Spartina cytotype to deal with increased abiotic severity (e.g., by effective root oxygenation; cf. Koop-Jakobsen and Wenzhöfer 2015), resulting in niche shifts (cf. Levin 2003) towards lower elevated habitats with increased flooding frequencies.

Niche differences between cytotypes have already been demonstrated in salt marshes for the genus Salicornia (Chenopodiaceae). Here, diploid (Salicornia europaea) and tetraploid (Salicornia stricta, Salicornia procumbens) cytotypes (König 1939) co-occur with genetically little differentiated lineages (Kadereit et al. 2007). These Salicornia cytotypes show considerable phenotypic plasticity, which may be a suitable mechanism of pioneer species to cope with high dynamics of abiotic conditions in salt marshes (Kadereit et al. 2007). Furthermore, Salicornia cytotypes have clear preferences to grow in specific salt marsh habitats (König 1960): The diploid Salicornia cytotype mainly occurs in low marshes and thus on higher elevations compared to the tetraploid Salicornia cytotype, which mainly occurs further down in the pioneer zone (König 1960; Teege et al. 2011; Witte et al. 2018). In Spartina, the dodecaploid cytotype has also been shown in reciprocal transplant experiments to exhibit high phenotypic plasticity, i.e., distinct morphologies related to the growth conditions (Thompson et al. 1991a, b). During our preliminary studies, the hexaploid cytotype showed comparatively higher stem 
density. However, detailed knowledge on morphology and ecological niches of Spartina cytotypes is still lacking.

Approximately 90 years ago, Spartina fragments were planted in the European Wadden Sea in land reclamation experiments (especially for sediment trapping and marsh surface stabilization; Thijsse 1924; König 1948; Esselink 1998; Nehring and Hesse 2008). Almost all planted fragments originated from Poole Harbour, approximately $30 \mathrm{~km}$ southwest of Southampton (UK), where both Spartina cytotypes co-occurred (Ranwell 1967; Raybould 2005). Most likely, fragments of both the hexaploid and dodecaploid cytotype were introduced to the Wadden Sea area. Since the middle of the twentieth century, Spartina has widely increased in abundance in salt marshes of the Wadden Sea (Esselink et al. 2017). However, most of the studies on salt marsh vegetation of the Wadden Sea did not distinguish between the Spartina cytotypes. In addition, the name of Spartina anglica is sometimes synonymously used for both Spartina anglica and the $\mathrm{F}_{1}$-hybrid Spartina $\times$ townsendii (e.g., Nehring and Adsersen 2006). Therefore, ecological differences between Spartina cytotypes may have been widely ignored and the $\mathrm{F}_{1}$-hybrid been overlooked. The objectives of this study are to analyze the geographic distribution of both Spartina cytotypes in the Wadden Sea area, and to compare their ecological niches along the elevational salt marsh gradient. We tested the following hypotheses:

1) Hexa- and dodecaploid Spartina cytotypes occur along the Wadden Sea coast with similar frequencies. To test this, we scanned for Spartina cytotypes along a European Wadden Sea transect from Den Helder (The Netherlands) through Lower Saxony and Schleswig Holstein (Germany) to Skallingen (Denmark). We determined the cytotypes' frequencies for six regions in our focus area, i.e., the mainland salt marshes in Schleswig-Holstein.

2) The hexa- and dodecaploid Spartina cytotypes show distinguishable phenotypes. To verify this hypothesis, we determined the cover as proxy for stem density of Spartina phenotypes in the focus area.

3) Due to increased stress tolerance as a consequence of WGD, the ecological niche of the dodecaploid cytotype includes the most stressful habitats within the frequently flooded pioneer zone of the salt marsh. This

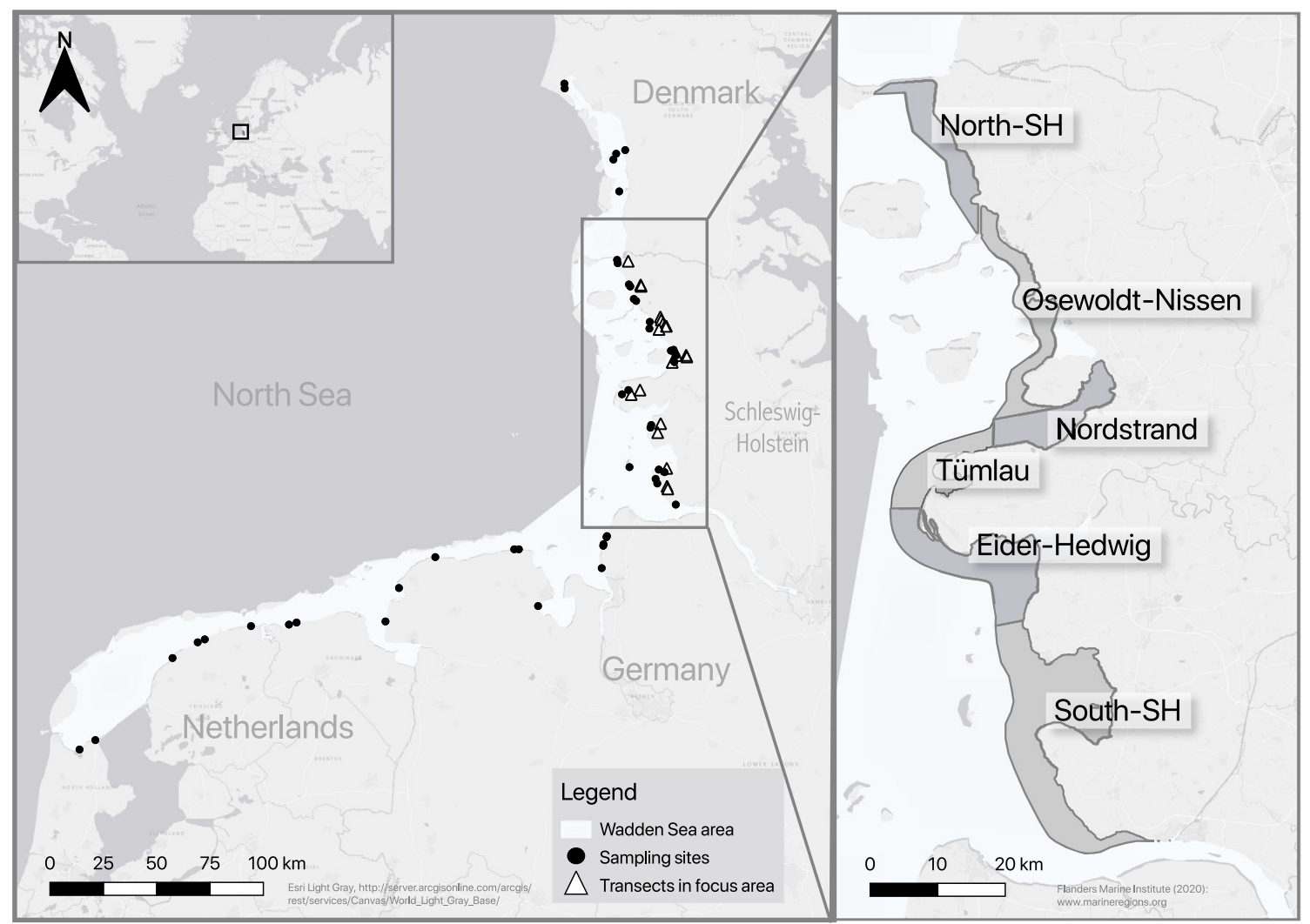

Fig. 1 Spartina sampling sites (black dots) in mainland salt marshes along the European Wadden Sea coast (left side frame) and transects (white triangles) in six regions of the focus area (right side frame) in Schleswig-Holstein (SH), Germany 
hypothesis was tested by comparing the response of both Spartina cytotypes to elevation.

\section{Materials and Methods}

\section{Study Area}

For an initial scan of the geographical distribution of Spartina cytotypes, 96 plots covered by Spartina were investigated in salt marshes of the European Wadden Sea (Fig. 1). From Den Helder in the Netherlands to Skallingen, Denmark, plant material was collected in 2017/18 from Spartina clones at sites approximately $50 \mathrm{~km}$ in distance to each other. From 2017 to 2019, Spartina was additionally sampled along 19 transects in mainland salt marshes at the North Sea coast of Schleswig-Holstein, Germany, hereafter referred to as focus area. In the focus area, the transects were arranged as described in Granse et al. (2021). Accounting for differences in tidal range, the focus area was split into six regions (Fig. 1) related to groups of equal tidal ranges and by following the regional tide-gauges classifications from Balke et al. (2016). Each of the 19 sampled transects spanned the elevational gradient from bare tidal flats to high marsh communities.

Information on Spartina plantings in the focus area was taken from König (1948). The northernmost Spartina planting site and the northernmost Spartina occurrence in 1947 was near Dagebüll in the Osewoldt-Nissen region (König 1948). We used the geographic distance between the northernmost planting site and today's northernmost occurrence of Spartina to estimate dispersal distances of Spartina cytotypes.

\section{Cytotypes}

Two major cytotypes of Spartina taxa can be found in the salt marshes of the study area (cf. Hubbard and Sampson 1992), one being hexa- and one being dodecaploid. The hexaploid cytotype includes the $\mathrm{F}_{1}$-hybrid Spartina $\times$ townsendii $(2 n=62$, Marchant 1968), as well as its parental taxa Spartina alterniflora $(2 n=62$, Marchant 1968) and Spartina maritima $(2 n=60$, Marchant 1968). The dodecaploid cytotype is represented by Spartina anglica $(2 n=$ 120, 122, or 124, Marchant 1968). The hexa- and dodecaploid cytotypes were distinguished by means of nuclear DNA content (cf. Baumel et al. 2003; Dolezel et al. 2007) using flow cytometry and a DAPI-staining protocol (cf. Galbraith et al. 1983). Fresh young leaves from a Spartina clone and fresh leaves of Pisum sativum (standard) were cochopped (Hanson et al. 2005) with a new razor in $0.5 \mathrm{ml}$ staining buffer (CyStain UV Ploidy DAPI staining solution, Partec, Germany) for $30 \mathrm{~s}$. After addition of $0.5 \mathrm{ml}$ staining buffer and $30 \mathrm{~s}$ of incubation, the solution was filtered with a $30 \mu \mathrm{m}$ mesh and analyzed in a flow-cytometer (Partec GmbH, Münster, Germany). The resulting fluorescence peaks were accepted when peak height exceeded a nuclei count of 50 with a coefficient of variation (CV) smaller than $8 \%$ (cf. Suda and Trávníček 2006; Doležel and Bartoš 2005).

Hexaploid cytotype taxa were distinguished according to morphological differences (e.g., Saarela 2012). In cases of hexaploid clones with ambiguous morphology, taxon affiliation (Spartina $\times$ townsendii, Spartina alterniflora) was determined for flowering plants in the greenhouse by means of pollen viability analysis using microscopy (Marchant 1968; Partridge 1987). Pollen viability was assessed by differential staining of aborted and non-aborted pollen grains (Peterson et al. 2010). Pollen abortion is often indicative of failures in chromosome segregation during meiosis. Indeed, chromosome spreads of male meiocytes revealed multivalent and missegregated chromosomes as often observed in polyploid species (Marchant 1968; Ramsey and Schemske 2002).

\section{Spartina Phenotypic Variation and Spartina Cytotype Sampling}

To analyze intercytotypic differences in phenotypes, Spartina cover was recorded on 1029 plots of $1 \times 1 \mathrm{~m}^{2}$ in the focus area. The positions of the plots were the same as the plots described in Granse et al. (2021) which are based upon 362 resampled plots from a 30-year-old initial vegetation study (Suchrow and Jensen 2010) and 667 additional plots located in newly developed salt marsh areas. The plots were arranged in clusters at 50-400 m intervals along each transect (see Online Resource, Fig. 5). Within a cluster and to ensure methodological continuity with Suchrow and Jensen (2010), the plot positions were selected by considering the spectrum of visually distinguishable vegetation units. Therefore, plots were placed side-by-side accounting for small-scale changes in vegetation or positioned at some distance where vegetation changed on a larger scale, e.g., at isolated Spartina clones surrounded by the mudflat.

Spartina cover was visually estimated as a percentage value at the herb layer (Mueller-Dombois and Ellenberg 1974, "basal" cover) of plants which were rooting on the plot ("rooted" cover; Dengler 2008). Due to the upright protruding stem morphology of Spartina plants, according to our preliminary studies, "rooted" and "basal" assessed vegetation cover directly translates into stem density reflecting the Spartina phenotype.

In order to assign a Spartina cytotype to a plot, a fragment from a Spartina plant of the plot's dominant Spartina phenotype was cut and cultivated in the greenhouse at Universität Hamburg until cytotype determination. Usually, 
one phenotype was observed per plot which extended in some cases largely over the sampling area. Therefore, if the dominant Spartina phenotype extended over neighboring plots, one Spartina fragment was considered to be representative for plots in the vicinity of maximal $5 \mathrm{~m}$ around the sampling-position. Neighboring but differing Spartina phenotypes were visually distinguished from each other by means of spatially varying appearance, e.g., stem density, state of flowering, leaf color, leaf angle (Marchant 1967; Wong et al. 2018), and degree of claviceps infection (see Boestfleisch et al. 2015; Raybould 2005). For Spartina cytotype determination, these criteria allowed to pool plots by taking just one sample that represented two or more plots and hence reducing the sampling amount: pooling of two plots (70 cases), three plots (34 cases), four plots (14 cases), and five or more plots (2 cases). Overall, 417 sampled Spartina fragments were assigned to 607 plots (hexaploid: 88 to 108; dodecaploid: 329 to 499). The frequency of Spartina cytotypes is reported as the proportion of plots with the respective cytotype of all regarded plots within a region.

\section{Elevation}

As a basis for analyzing the ecological niche of both Spartina cytotypes along the elevational salt marsh gradient, elevation of all 1122 plots (including 93 uncovered plots) in the focus area was determined by means of a Laser Leveling device (LL500 combined with HL700 receiver by Trimble, CA, USA) and by averaging five elevation measurements per plot as described in Granse et al. (2021). The elevation of plots was calculated in relation to nearby benchmarks of the vertical control survey-net of the German height reference system or to permanently installed sedimentation erosion bars. Measured values were related to the German height reference system (absolute elevation value; $\mathrm{cm} \mathrm{NN}$ ). In line with Suchrow and Jensen (2010), a mean high tide value $(\mathrm{cm}$ MHT) was calculated for each transect by interpolation between two adjacent tide gauges from the previous "water year". Via this MHT value, for each plot along a transect its position in relation to MHT was calculated.

\section{Niche Differentiation}

Ecological niche analysis was conducted by means of HOF-modeling (Huisman et al. 1993) with elevation as a proxy for flooding frequency and flooding duration, which represents increasing abiotic severeness with decreasing elevation (Adam 1993; Suchrow and Jensen 2010). The response (presence on plots) of Spartina cytotypes to elevation was fitted to one out of seven HOF-model types (Jansen and Oksanen 2013) by using the eHOF-package in R (Oksanen and Minchin 2002). The best-fitted model was selected by means of the AICc estimator after calling the HOF-function with standard parameter against the binomial error distribution family and with a bootstrap of 100 (for HOF-model parameters see Online Resource, Tables 1-3). The HOF-modeling reports a raw mean (mean of the observed variable), a niche-optimum (value along the gradient with highest predicted occurrence) and an expectancy (calculated as a mean of 10,000 values along the gradient weighted by their predicted occurrence; for details see Jansen and Oksanen 2013). Converging values of raw mean, optimum and expectancy indicate a high goodness of fit for the resulting model. In addition, the observed frequency of occurrence of Spartina cytotypes was transformed into a binary presence/absence-status (presence: cover $>0$; absence: cover $=0$ ). The binary status was grouped over binning classes of $10 \mathrm{~cm}$ MHT of elevation and allowed a visual comparison of observed vs. predicted data.

\section{Statistics and Software}

Frequencies of Spartina cytotypes in the entire focus area were compared by means of Fisher's exact test for count data. To test for differences between Spartina cytotypes in elevation and Spartina cover, non-parametric MannWhitney $U$-tests were used because the data was not normally distributed. Statistic evaluation was conducted by calling routines from R-packages of version 3.6.1 ( $\mathrm{R}$ Development Core Team 2011). Analysis of dispersal distances between the northernmost planting site and the current northernmost occurrence in a specific transect was conducted using QGIS 3 (Madeira) with HCMGIS-plugin (including Esri World Light Grey Basemap) and Marine Regions shape file (Flanders Marine Institute 2020).

\section{Results}

\section{Geographic Distribution}

The dodecaploid cytotype (Spartina anglica) was present along the entire European Wadden Sea coast (Fig. 2), whereas the hexaploid cytotype (Spartina $\times$ townsendii) only occurred in the northeast, from Wangerland in Lower Saxony (Germany) to Skallingen (Denmark). In each of the regions in the focus area, the frequency of the dodecaploid cytotype was higher than that of the hexaploid, and the frequency of the hexaploid cytotype varied considerably between the regions (Fig. 2; Online Resource, Table 4). The highest frequency of the hexaploid $(24.4 \% ; n=$ 127) was found north of the peninsula of Eiderstedt. Both the hexaploid- and the dodecaploid cytotype were present 


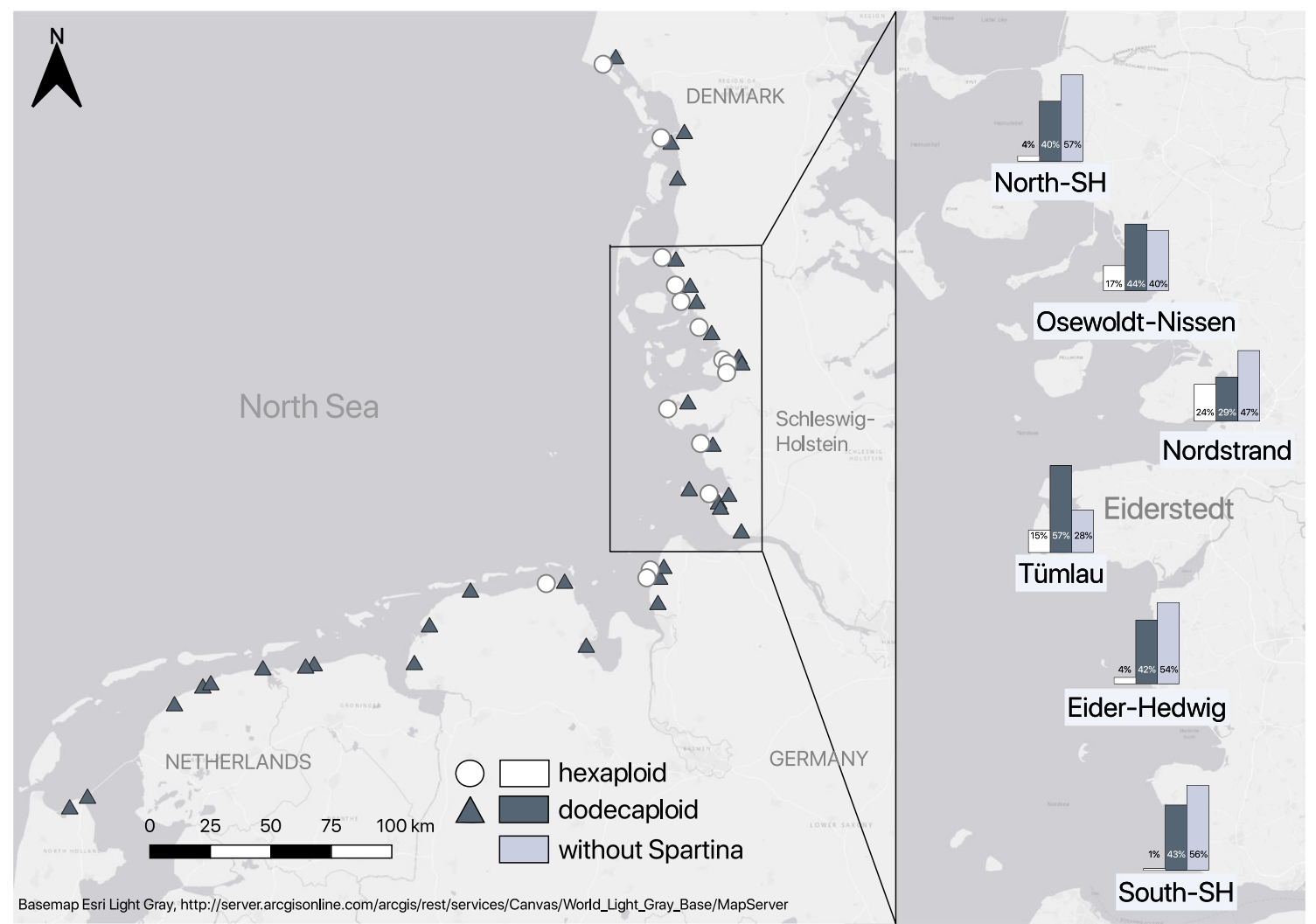

Fig. 2 Distribution of Spartina cytotypes (hexa- and dodecaploid) at sampling sites in mainland salt marshes in the European Wadden Sea (left side frame) and in the focus area (right side frame) along the North Sea coast of Schleswig-Holstein (SH), Germany. The bar-charts show

in the North region, approximately $20 \mathrm{~km}$ north of the northernmost planting site.

A hexaploid Spartina alterniflora clone was found near the island of Mandø, Denmark, while Spartina maritima was not observed in the study area. We did not observe nonaploids or other forms of intermediate backcrossing between the hexa- and dodecaploid Spartina cytotypes. Spartina $\times$ townsendii plants did not show any viable pollen, while the pollen of Spartina anglica appeared to be mostly intact (see Online Resource, Fig. 6).

\section{Cytotype Frequency, Elevation and Spartina Cover}

In the focus area, the dodecaploid cytotype was more frequent on vegetated plots than the hexaploid cytotype (Fig. 3a). In comparison with the dodecaploid cytotype, the hexaploid cytotype colonized plots at significantly lower elevations (Fig. 3b). At the lowest elevations near $-86.0 \mathrm{~cm}$ MHT, the hexaploid cytotype occurred with both higher plot cover and frequency compared to the only occasionally occurring dodecaploid cytotype (see outliers in Fig. 3b). The Spartina cover was generally higher on plots with the the frequency of the hexa- and dodecaploid Spartina cytotype as well as plots without Spartina, separately for the six regions of the focus area $(n=883$; see also Online Resource, Table 4$)$

hexaploid cytotype (median: 25\%; Fig. 3c) than on plots with the dodecaploid cytotype (median: 12\%).

\section{Niche Differentiation}

The HOF-model type $\mathrm{V}$ was the best fitted model type for the elevational response of the dodecaploid, i.e., a unimodal curve with an optimum at $8.0 \mathrm{~cm}$ MHT and a probability of occurrence of the dodecaploid about $83.8 \%$ at this elevation (Fig. 4). The niche-optimum and expectancy had approximately the same value and differed from the raw mean only slightly by $7.1 \mathrm{~cm}$.

The response of the hexaploid cytotype to elevation was best described by model type IV. The model predicted a niche-optimum at $-49.5 \mathrm{~cm}$ MHT with a probability of occurrence of $22.6 \%$. In comparison with the dodecaploid cytotype, niche-optimum and expectancy of the hexaploid cytotype were equal with a higher difference to raw mean. Nonetheless, for both cytotypes a good agreement on the model prediction was indicted by a relatively high similarity between predicted and observed data (see also detailed HOF-model diagrams in Online Resource, Fig. 7 and 

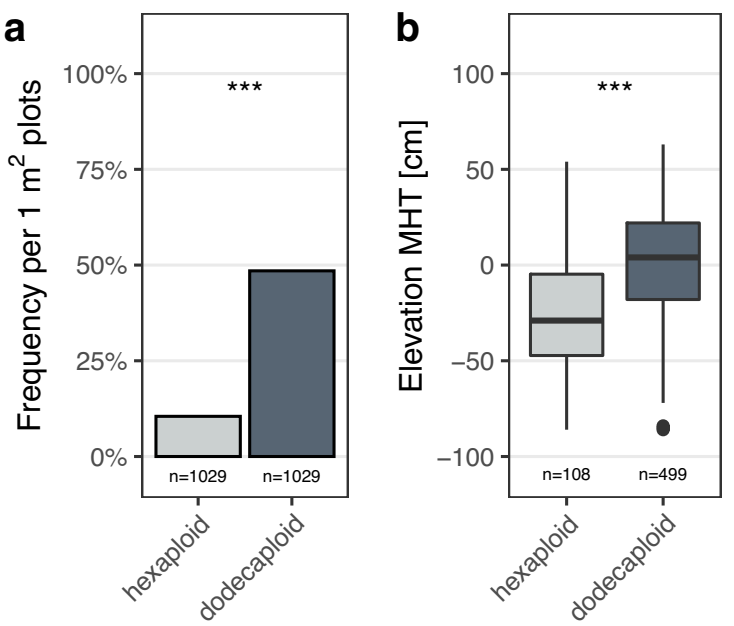

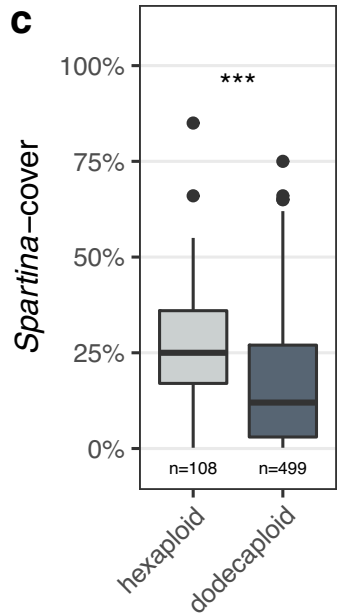

Fig. 3 a Frequency of Spartina cytotypes (hexa- and dodecaploid) on plots along transects of the focus area $\left({ }^{* * *}\right.$ : Fisher's exact test for count data; $P<0.001 ; n$ : plots). b Occurrence of Spartina cytotypes on plots in the focus area in relation to elevation MHT (***: Mann-Whitney $U$-test, $U=52.6, P<0.001, d f=1)$. c Cover of

predicted HOF-model responses in Online Resource, Table 3).

\section{Discussion}

Detailed studies with respect to the geographic distribution of Spartina cytotypes in the European Wadden Sea have been lacking so far. With this study, we show that two different Spartina cytotypes occur in the mainland salt marshes along the Wadden Sea coast, the hexaploid $F_{1}$ hybrid Spartina $\times$ townsendii as well as the maternal Spartina alterniflora, and the hybrid's dodecaploid descendent Spartina anglica. However, we reject our first hypothesis of expecting evenly distributed cytotypes because the hexaploid cytotype mainly occurred in eastern parts of the study area with varying frequencies, while the dodecaploid cytotype was regularly present along the entire Wadden Sea coast. The presence of hexaploid Spartina alterniflora near the island of Mandø, Denmark, confirms two earlier records reporting its occurrence in Denmark (Møller et al. 2018). The Danish region is therefore a suitable study area for further investigations of backcrosses between Spartina anglica and Spartina alterniflora (cf. Renny-Byfield et al. 2010; Huska et al. 2016). Crosses between Spartina $\times$ townsendii and Spartina anglica would be highly unlikely because of the strict infertility of Spartina $\times$ townsendii. The meiotic defects reflected by the pollen inviability of Spartina $\times$ townsendii indicate that selective evolution can be widely excluded as an explanation for the distribution pattern of the hexaploid $\mathrm{F}_{1}$-hybrid.
Spartina cytotypes on plots in the focus area ${ }^{* * *}$ : Mann-Whitney $U$ test, $U=33.5, P<0.001, d f=1)$. In the boxplots, the median is displayed as horizontal line and outliers as dots outside the 1.5 of the interquartile range (box and whiskers)

In the southwestern Wadden Sea, the hexaploid Spartina cytotype was reported to be a rare species with two records on island salt marshes in the Netherlands in the 1950s (Mennema et al. 2013). We cannot rule out that we overlooked sporadic occurrences of the hexaploid Spartina cytotype in the southwestern Wadden Sea area due to our sampling method with $50 \mathrm{~km}$ distance between sampling positions. Nevertheless, the main distribution area of the hexaploid cytotype was restricted to the eastern parts of the Wadden Sea. This might be explained by differences in climate and geomorphology. The north-south trending Wadden Sea developed differently from the east-west trending Wadden Sea (Wiersma et al. 2009). While the latter Wadden Sea area was reported to be stable, the

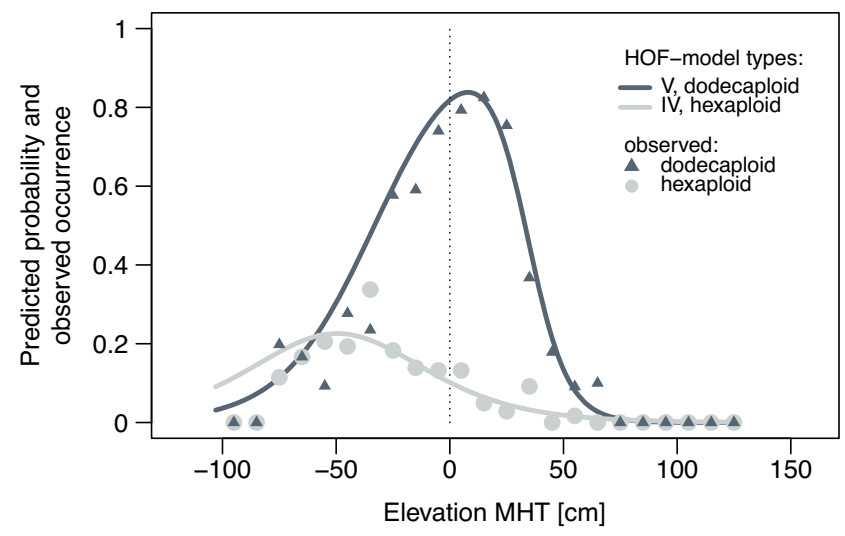

Fig. 4 HOF-modeled presence/absence response curves and observed frequencies of hexa- and dodecaploid Spartina cytotypes along the elevational gradient ( $n=1094$ plots) 
northeastern part is undergoing land loss or subsidence. Furthermore, the northeastern part has colder winters (Oost et al. 2017; Philippart et al. 2017). Whether the hexaploid cytotype benefits from high geomorphodynamics in the eastern part and/or the dodecaploid cytotype is favored by milder climate in the southwestern part of the Wadden Sea needs to be tested in additional studies.

The hexaploid cytotype occurred with the highest frequency in the region north to the peninsula of Eiderstedt and in relative vicinity to former planting sites (Bay of Nordstrand, e.g., Sophien-Sommer-Koog or Dockkoog, König 1948). Presumably, these plants were donors of hexaploid clones which could establish in areas without Spartina plantings (cf. König 1948). Although the frequency of the hexaploid cytotype decreased with increasing geographic distance to the donor plantings, it spread vegetatively over dispersal distances comparable to the dispersal distances of the dodecaploid cytotype. This underpins the important role of vegetative spreading of polyploids (Herben et al. 2017). Besides vegetative spread, both the capacity for seed production (Marchant 1967; Hubbard 1970; Gray et al. 1990) and long-lasting floating of seeds in sea water (Marks and Truscott 1985; Huiskes et al. 1995; Koutstaal et al. 1987) may have increased the establishment success of the dodecaploid cytotype compared to the hexaploid (cf. Loebl et al. 2006; te Beest et al. 2012). In line with Glennon et al. (2014), who showed that dispersal capabilities can explain polyploid persistence in the long term, differences in spreading efficiency may explain why the hexa- and dodecaploid Spartina cytotypes differed widely in frequency along the geographic range of the study area.

Hexa- and dodecaploid Spartina cytotypes occurred with distinguishable phenotypes, which was reflected by different Spartina cover. This supports our second hypothesis. Stem density is an important factor controlling the capacity to catch suspended sediment and stabilize the marsh surface against sediment re-suspension by reducing the turbulent kinetic energy of water currents (Mudd et al. 2010; Tinoco and Coco 2018). Therefore, differences in Spartina cover may imply that the hexa- and dodecaploid cytotypes differ in their role in ecosystem functioning (van Hulzen et al. 2007; Bouma et al. 2009). Further investigations of Spartina cytotypes with respect to their contribution to ecosystem functioning are therefore strongly recommended.

The hexa- and dodecaploid cytotypes differed only slightly in their range of occurrence along the elevational gradient, although the estimated optimum of the hexaploid cytotype was approximately $50 \mathrm{~cm}$ lower than that of the dodecaploid. This did not support our third hypothesis. WGD in Spartina did not increase the capacity to colonize stressful habitats at the lower end of the elevational gradient. In tidal areas, decreases in elevation, even in the centimeter range, translate directly into increases in both frequency and duration of flooding, and thus in abiotic stress (Maricle and Lee 2007; Engels et al. 2011; Davy et al. 2011) as well as increased biomechanical stress induced by winterice scrub and wave dynamics (Widdows et al. 2008). Regarding assumed abiotic and biophysical stressors, our data reflect that WGD in Spartina did not necessarily increase fitness nor change the niche breadths (cf. Visser and Molofsky 2015; Casazza et al. 2016; McIntyre and Strauss 2017). The hexaploid $F_{1}$-hybrid already showed the capacity to cope with these stressors proxied by elevation.

In contrast to Salicornia, the occurrence of Spartina cytotypes along the elevational gradient was not clearly constricted to marsh zones. In Salicornia, the cytotype with the larger genome (tetraploid) prefers habitats at low elevations, whereas it is replaced by the diploid Salicornia cytotype at higher and less stressful elevations (König 1960; Piirainen 2015; Witte et al. 2018). In Spartina, the cytotype with the larger genome (dodecaploid) was more frequent on high elevations than the hexaploid cytotype. This shows that WGD seems not to be a universal mechanism to increase the capacity for coping with abiotic severity.

Other factors than the above-mentioned may have been the reason for the differences in marsh zone preferences between Spartina and Salicornia cytotypes. While Spartina is perennial, in the annual Salicornia, seed germination and success of seedling establishment may select for the habitat which is specific for the respective cytotype (Witte et al. 2018). Furthermore, diversification in Salicornia is based on at least two independent WGD events (Kadereit et al. 2007). Therefore, habitat preferences in Salicornia cytotypes might be related to specific genotypes (Teege et al. 2011) because genetic variability can increase the ecological amplitude (e.g., Meimberg et al. 2009). Opposed to this, WGD in Spartina is assumed to be a unique event (Baumel et al. 2001; Ainouche et al. 2012) followed by a relatively short evolutionary history. A short evolutionary history after WGD did not allow for accumulation of genetic differences between Spartina cytotypes (Ramsey 2011; Soltis et al. 2016). Thus, differences in habitat preferences in Spartina, as indicated by differences in niche-optimum between Spartina cytotypes, are likely based on adaptive responses and competitive interaction between the cytotypes, and not on genetic diversification.

The hexaploid Spartina cytotype showed its optimum occurrence lower along the elevation gradient, presumably due to competitive exclusion by the dodecaploid cytotype (cf. Gray et al. 1990; Glennon et al. 2014; Casazza et al. 2016). Once established, the dodecaploid Spartina cytotype can show biotic resistance to the colonization of its patches by other closely related cytotypes (Proença et al. 2019). The first colonizing Spartina cytotype obviously gains advantage in long-term establishment. This is well 
reflected by the observation that the hexaploid cytotype is still dominant in salt marsh areas near the hybridization site in Britain (Renny-Byfield et al. 2010; Huska et al. 2016). Elsewhere, the hexaploid $F_{1}$-hybrid may have been overlooked due to low establishment success. However, it may have a similar competitive capacity to its dodecaploid descendent. Therefore, competitive interactions between Spartina cytotypes require further experimental testing.

\section{Conclusions}

The hexaploid $\mathrm{F}_{1}$-hybrid Spartina $\times$ townsendii and its dodecaploid descendent Spartina anglica occur with vital stands in European Wadden Sea mainland salt marshes. While the dodecaploid cytotype was present along the entire coast, the presence of the hexaploid cytotype was mostly confined to the northeastern parts of the Wadden Sea with regionally varying frequency. We infer that the hexaploid cytotype mainly established in vacant niches at the lower end of the elevational gradient where abiotic stress was presumably more severe but intercytotypic competition decreased. By contrast, in the dodecaploid Spartina cytotype, WGD increased the capacity for more efficient establishment along the geographic gradient but did not increase the capacity for establishment in stressful habitats or highly dynamic environments. Further studies are required to quantify differences between Spartina cytotypes in plant traits, performance, and their diverging role in ecosystem functioning of salt marshes.

Supplementary Information The online version contains supplementary material available at https://doi.org/10.1007/s12237-021-00985-4.

Acknowledgements We thank all members of the laboratory of Malika Ainouche, University of Rennes, France, for confirming our cytotypic data, and Peter Esselink for the sampling of Spartina plants in the Netherlands and helpful advice. Many thanks go to Hong Zhou and Vera Schwekendiek for providing expertise and advising into genome-size analysis. Special thanks to Jonas Kotlarz, Tore Mayland-Quellhorst, and Michael Bewerungen, as Spartina sampling on the island of Trischen would not have been possible without their great commitment. We further thank the authorities from the Nationalpark Schleswig-Holsteinisches Wattenmeer for the authorization of our fieldwork and for providing tidal data, as well as the Wasserstraßen- und Schifffahrtsamt Tönning, and the Landesbetrieb für Küstenschutz, Nationalpark und Meeresschutz for providing tide gauge measurement data. We also thank all authorities outside the focus area for their consent for access to their marshes and collecting plant material. All work was conducted in the framework of the project "Hybrids - Chances and Challenges of New Genetic Combinations", Universität Hamburg. We also thank the anonymous reviewers for their constructive and helpful suggestions.

Author Contributions All authors contributed to the study conception and design. Vegetation assessments and data compilation were performed by Sigrid Suchrow and Dirk Granse. Mariana Motta conducted the pollen viability analysis. The data analysis was performed and the first draft of the manuscript was written by Dirk
Granse. All authors commented on previous versions of the manuscript and all authors read and approved the final manuscript.

Funding Open Access funding enabled and organized by Projekt DEAL.

\section{Declarations}

Conflict of Interest The authors declare no competing interests.

Open Access This article is licensed under a Creative Commons Attribution 4.0 International License, which permits use, sharing, adaptation, distribution and reproduction in any medium or format, as long as you give appropriate credit to the original author(s) and the source, provide a link to the Creative Commons licence, and indicate if changes were made. The images or other third party material in this article are included in the article's Creative Commons licence, unless indicated otherwise in a credit line to the material. If material is not included in the article's Creative Commons licence and your intended use is not permitted by statutory regulation or exceeds the permitted use, you will need to obtain permission directly from the copyright holder. To view a copy of this licence, visit http://creativecommons. org/licenses/by/4.0/.

\section{References}

Adam, P. 1993. Saltmarsh Ecology. Cambridge: Cambridge University Press.

Ainouche, M, H Chelaifa, J Ferreira, S Bellot, A Ainouche, and A Salmon. 2012. Polyploid Evolution in Spartina: Dealing with Highly Redundant Hybrid. In Genomes Polyploidy and Genome Evolution, chap 12, pp 225-243, eds. P.S. Soltis, and D.E. Soltis. Berlin: Springer. https://doi.org/10.1007/978-3-642-31442-1_12.

Ainouche, ML, A Baumel, A Salmon, and G Yannic. 2003. Hybridization, polyploidy and speciation in Spartina (Poaceae). New Phytologist 161(1): 165-172. https://doi.org/10.1046/j.14698137.2003.00926.x.

Bakker, JP, M Schrama, P Esselink, P Daniels, N Bhola, S Nolte, Y de Vries, RM Veeneklaas, and M Stock. 2020. Long-term effects of sheep grazing in various densities on marsh properties and vegetation dynamics in two different salt-marsh zones. Estuaries and Coasts 43(2): 298-315. https://doi.org/10.1007/s12237019-00680-5.

Balke, T, M Stock, K Jensen, TJ Bouma, and M Kleyer. 2016. A global analysis of the seaward saltmarsh extent: The importance of tidal range. Water Resources Research 52(5): 3775-3786. https://doi.org/10.1002/2015WR018318.

Barker, MS, N Arrigo, AE Baniaga, Z Li, and DA Levin. 2016a. On the relative abundance of autopolyploids and allopolyploids. New Phytologist 210(2): 391-398. https://doi.org/10.1111/nph.13698.

Barker, MS, BC Husband, and JC Pires. 2016b. Spreading Winge and flying high: The evolutionary importance of polyploidy after a century of study. American Journal of Botany 103(7): 1139-1145. https://doi.org/10.3732/ajb.1600272.

Baumel, A, ML Ainouche, and JE Levasseur. 2001. Molecular investigations in populations of Spartina anglica C.E. Hubbard (Poaceae) invading coastal Brittany (France). Molecular Ecology 10(7): 1689-1701. https://doi.org/10.1046/j.1365-294X. 2001.01299.x.

Baumel, A, ML Ainouche, MT Misset, JP Gourret, and RJ Bayer. 2003. Genetic evidence for hybridization between the native Spartina maritima and the introduced Spartina alterniflora 
(Poaceae) in South-West France: Spartina $\times$ neyrautii reexamined. Plant Systematics and Evolution 237(1): 87-97. https://doi.org/10.1007/s00606-002-0251-8.

Birchler, JA. 2012. Genetic Consequences of Polyploidy in Plants. In Polyploidy and Genome Evolution, chap 2, pp 21-32, eds. P.S. Soltis, and D.E. Soltis. Berlin: Springer. https://doi.org/10.1007/ 978-3-642-31442-1_2.

Boestfleisch, C, AM Drotleff, W Ternes, S Nehring, S Pažoutová, and J Papenbrock. 2015. The invasive ergot Claviceps purpurea var. spartinae recently established in the European Wadden Sea on common cord grass is genetically homogeneous and the sclerotia contain high amounts of ergot alkaloids. European Journal of Plant Pathology 141(3): 445-461. https://doi.org/10.1007/s10658-014-0555-x.

Bortolus, A, P Adam, JB Adams, ML Ainouche, D Ayres, MD Bertness, TJ Bouma, JF Bruno, I Caçador, JT Carlton, JM Castillo, CSB Costa, AJ Davy, L Deegan, B Duarte, E Figueroa, J Gerwein, AJ Gray, ED Grosholz, SD Hacker, AR Hughes, E Mateos-Naranjo, IA Mendelssohn, JT Morris, AF MuñozRodríguez, FJJ Nieva, LA Levin, B Li, W Liu, SC Pennings, A Pickart, S Redondo-Gómez, DM Richardson, A Salmon, E Schwindt, BR Silliman, EE Sotka, C Stace, M Sytsma, S Temmerman, RE Turner, I Valiela, MP Weinstein, and JS Weis. 2019. Supporting Spartina: interdisciplinary perspective shows Spartina as a distinct solid genus. Ecology 100(11): e02863. https://doi.org/10.1002/ecy.2863.

Bouma, TJ, M Friedrichs, BK Van Wesenbeeck, S Temmerman, G Graf, and PMJ Herman. 2009. Density-dependent linkage of scale-dependent feedbacks: a flume study on the intertidal macrophyte Spartina anglica. Oikos 118(2): 260-268. https://doi.org/10.1111/j.1600-0706.2008.16892.x.

Brochmann, C, AK Brysting, IG Alsos, L Borgen, HH Grundt, AC Scheen, and R Elven. 2004. Polyploidy in arctic plants. Biological Journal of the Linnean Society 82(4): 521-536. https://doi.org/10.1111/j.1095-8312.2004.00337.x.

Casazza, G, FC Boucher, L Minuto, CF Randin, and E Conti. 2016. Do floral and niche shifts favour the establishment and persistence of newly arisen polyploids? A case study in an Alpine primrose. Annals of Botany 119(1): 81-93. https://doi.org/10.1093/aob/mcw221.

Cavé-Radet, A, A Salmon, O Lima, M Ainouche, and A EL Amrani. 2019. Increased tolerance to organic xenobiotics following recent allopolyploidy in Spartina (Poaceae). Plant Science 280: 143-154. https://doi.org/10.1016/j.plantsci.2018.11.005.

Čertner, M, E Fenclová, P Kúr, F Koláŕ, P Koutecký, A Krahulcová, and J Suda. 2017. Evolutionary dynamics of mixed-ploidy populations in an annual herb: dispersal, local persistence and recurrent origins of polyploids. Annals of Botany 120(2): 303-315. https://doi.org/10.1093/aob/mcx032.

Charron, G, S Marsit, M Hénault, H Martin, and CR Landry. 2019. Spontaneous whole-genome duplication restores fertility in interspecific hybrids. Nature Communications 10(1): 4126. https://doi.org/10.1038/s41467-019-12041-8.

Chelaifa, H, F Mahé, and M Ainouche. 2010. Transcriptome divergence between the hexaploid salt-marsh sister species Spartina maritima and Spartina alterniflora (Poaceae). Molecular Ecology 19(10): 2050-2063. https://doi.org/10.1111/j.1365-294X.2010.04 637.x.

Colmer, TD, and TJ Flowers. 2008. Flooding tolerance in halophytes. New Phytologist 179(4): 964-974. https://doi.org/10.1111/j.14698137.2008.02483.x.

Davy, AJ, MJH Brown, HL Mossman, and A Grant. 2011. Colonization of a newly developing salt marsh: disentangling independent effects of elevation and redox potential on halophytes. Journal of Ecology 99(6): 1350-1357. https://doi.org/10.1111/j.1365-2745. 2011.01870.x.
Dengler, J. 2008. Pitfalls in small-scale species-area sampling and analysis. Folia Geobotanica 43(3): 269-287. https://doi.org/10.10 07/s12224-008-9014-9.

Doležel, J, and J Bartoš. 2005. Plant DNA flow cytometry and estimation of nuclear genome size. Annals of Botany 95(1): 99110. https://doi.org/10.1093/aob/mci005.

Doležel, J, J Greilhuber, and J Suda. 2007. Estimation of nuclear DNA content in plants using flow cytometry. Nature Protocols 2(9): 2233-2244. https://doi.org/10.1038/nprot.2007.310.

Drok, W. 1983. Is Spartina anglica Hubbard wel een goede soort? Gorteria Dutch Botanical Archives 11(11): 243-252. http:// natuurtijdschriften.nl/record/536510.

Ehrendorfer, F. 1980. Polyploidy and Distribution. In Polyploidy, ed. W. H. Lewis. Basic Life Sciences, vol 13. Springer, Boston. https://doi.org/10.1007/978-1-4613-3069-1_3.

Engels, JG, F Rink, and K Jensen. 2011. Stress tolerance and biotic interactions determine plant zonation patterns in estuarine marshes during seedling emergence and early establishment. Journal of Ecology 99(1): 277-287. https://doi.org/10.1111/j.1365-2745. 2010.01745.x.

Esselink, P. 1998. Van landaanwinning naar natuurbeheer: recente ontwikkelingen op de Dollardkwelders. In Het Eems-Dollard estuarium: interacties tussen menselijke beinvloeding en natuurlijke dynamiek, report RIKZ-98-020, Rijkswaterstaat-RIKZ, Haren, chap 6, eds. P. Esselink, and K. Essink, 79-99.

Esselink, P, WE Van Duin, J Bunje, J Cremer, EO Folmer, J Frikke, M Glahn, AV De Groot, N Hecker, U Hellwig, K Jensen, P Körber, J Petersen, and M Stock. 2017. Salt marshes. In Wadden Sea Quality Status Report 2017, eds. S. Kloepper et al., Common Wadden Sea Secretariat, Wilhelmshaven, Germany. Last updated 21.12.2017. Downloaded 25.12.2017. https://qsr. waddensea-worldheritage.org/reports/salt-marshes.

Ferreira de Carvalho, J, J Boutte, P Bourdaud, H Chelaifa, K Ainouche, A Salmon, and M Ainouche. 2017. Gene expression variation in natural populations of hexaploid and allododecaploid Spartina species (Poaceae). Plant Systematics and Evolution 303(8): 10611079. https://doi.org/10.1007/s00606-017-1446-3.

Flanders Marine Institute. 2020. Marineregions.org. available online at www.marineregions.org. consulted on 2020-04-30. http://www. marineregions.org.

Gaeta, RT, and JC Pires. 2010. Homoeologous recombination in allopolyploids: the polyploid ratchet. New Phytologist 186(1): 18-28. https://doi.org/10.1111/j.1469-8137.2009.03089.x.

Galbraith, DW, KR Harkins, JM Maddox, NM Ayres, DP Sharma, and E Firoozabady. 1983. Rapid Flow Cytometric Analysis of the Cell Cycle in Intact Plant Tissues. Science 220(4601): 1049-1051. https://doi.org/10.1126/science.220.4601.1049.

Glennon, KL, ME Ritchie, and KA Segraves. 2014. Evidence for shared broad-scale climatic niches of diploid and polyploid plants. Ecology Letters 17(5): 574-582. https://doi.org/10.1111/ele.12259.

Godfree, RC, DJ Marshall, AG Young, CH Miller, and S Mathews. 2017. Empirical evidence of fixed and homeostatic patterns of polyploid advantage in a keystone grass exposed to drought and heat stress. Royal Society Open Science 4(11). https://doi. org/10.1098/rsos.170934.

Granse, D, S Suchrow, and K Jensen. 2021. Long-term invasion dynamics of Spartina increase vegetation diversity and geomorphological resistance of salt marshes against sea level rise. Biological Invasions 23(3): 871-883. https://doi.org/10.1007/s10530-020-02408-0.

Gray, AJ, PEM Benham, and AF Raybould. 1990. Spartina anglica - the evolutionary and ecological background. In Spartina anglica - a research review, chap 1 pp 5-10, eds. AJ Gray, and PEM Benham. ITE research publication no.2. London, HMSO: Natural Environment Research Council. http://nora.nerc.ac.uk/id/eprint/7639/1/Spartina_Anglica.pdf. 
Hanson, L, A Boyd, MAT Johnson, and MD Bennett. 2005. First Nuclear DNA C-values for 18 Eudicot Families. Annals of Botany 96(7): 1315-1320. https://doi.org/10.1093/aob/mci283.

Herben, T, J Suda, and J Klimešová. 2017. Polyploid species rely on vegetative reproduction more than diploids: a re-examination of the old hypothesis. Annals of Botany 120(2): 341-349. https://doi.org/10.1093/aob/mcx009.

Hubbard, CE, and J Sampson. 1992. Grasses: a guide to their structure, identification, uses, and distribution in the British Isles, Pelican Books, Penguin Books.

Hubbard, JCE. 1969. Light in relation to tidal immersion and the growth of Spartina Townsendii (s.1.). Journal of Ecology 57(3): 795-804. https://doi.org/10.2307/2258500.

Hubbard, JCE. 1970. Effects of cutting and seed production in Spartina anglica. Journal of Ecology 58(2): 329-334. https:// doi.org/10.2307/2258274.

Huiskes, AHL, BP Koutstaal, PMJ Herman, WG Beeftink, MM Markusse, and W De Munck. 1995. Seed dispersal of halophytes in tidal salt marshes. Journal of Ecology 83(4): 559-567. https://doi.org/10.2307/2261624.

Huisman, J, H Olff, and LFM Fresco. 1993. A hierarchical set of models for species response analysis. Journal of Vegetation Science 4(1): 37-46. https://doi.org/10.2307/3235732.

van Hulzen, JB, J van Soelen, and TJ Bouma. 2007. Morphological variation and habitat modification are strongly correlated for the autogenic ecosystem engineer Spartina anglica (common cordgrass). Estuaries and Coasts 30(1): 3-11. https://doi.org/10.1007/BF02782962.

Huska, D, IJ Leitch, JF de Carvalho, AR Leitch, A Salmon, M Ainouche, and A Kovarik. 2016. Persistence, dispersal and genetic evolution of recently formed Spartina homoploid hybrids and allopolyploids in Southern England. Biological Invasions 18(8): 2137-2151. https://doi.org/10.1007/s10530-015-0956-6.

Jansen, F, and J Oksanen. 2013. How to model species responses along ecological gradients - Huisman-Olff-Fresco models revisited. Journal of Vegetation Science 24(6): 1108-1117. https://doi.org/ 10.1111/jvs.12050.

Kadereit, G, P Ball, S Beer, L Mucina, D Sokoloff, P Teege, AE Yaprak, and H Freitag. 2007. A taxonomic nightmare comes true: phylogeny and biogeography of glassworts (Salicornia L., Chenopodiaceae). Taxon 56(4): 1143-1170. https://doi.org/10.23 07/25065909.

König, D. 1939. Die Chromosomenverhältnisse der deutschen Salicornien. Planta 29(3): 361-375. http://www.jstor.org/stable/ 23356723.

König, D. 1948. Spartina Townsendii an der Westküste von Schleswig-Holstein. Planta 36(1): 34-70. https://doi.org/10.1007/ BF01917217.

König, D. 1960. Beiträge zur Kenntnis der deutschen Salicornien aus dem Landesamt für Wasserwirtschaft, Kiel. Mitteilungen der Floristisch-Soziologischen Arbeitsgemeinschaft 8: 5-58.

Koop-Jakobsen, K, and F Wenzhöfer. 2015. The dynamics of plant-mediated sediment oxygenation in Spartina anglica rhizospheres-a Planar Optode Study. Estuaries and Coasts 38: 951-963. https://doi.org/10.1007/s12237-014-9861-y.

Koutstaal, BP, MM Markusse, and W de Munck. 1987. Aspects of seed dispersal by tidal movements. In Vegetation between land and sea, eds. A.H.L. Huiskes, C.W.P.M. Blom, J. Rozema. Geobotany, vol 11. Springer, Dordrecht. https://doi.org/10.1007/978-94-009-4065-9_18.

Lafon-Placette, C, IM Johannessen, KS Hornslien, MF Ali, KN Bjerkan, J Bramsiepe, BM Glöckle, CA Rebernig, AK Brysting, PE Grini, and C Köhler. 2017. Endosperm-based hybridization barriers explain the pattern of gene flow between Arabidopsis lyrata and Arabidopsis arenosa in Central Europe. Proceedings of the National Academy of Sciences 114(6): E1027-E1035. https://doi.org/10.1073/pnas.1615123114.

Laport, RL, R Minckely, and J Ramsey. 2016. Ecological distributions, phenological isolation, and genetic structure in sympatric and parapatric populations of the Larrea tridentata polyploid complex. American Journal of Botany 103(7): 1358-1374. https://doi.org/10.3732/ajb.1600105.

de Leeuw, J, A van den Dool, W de Munck, J Nieuwenhuize, and WG Beeftink. 1991. Factors influencing the soil salinity regime along an intertidal gradient. Estuarine, Coastal and Shelf Science 32(1): 87-97. https://doi.org/10.1016/0272-7714(91)90030-F.

Leitch, A, and I Leitch. 2008. Genomic plasticity and the diversity of polyploid plants. Science 320(5875): 481-483. https://doi.org/10.1126/science.1153585.

Levin, DA. 1975. Minority cytotype exclusion in local plant populations. Taxon 24(1): 35-43. https://doi.org/10.2307/1218997.

Levin, DA. 2003. The ecological transition in speciation. The New Phytologist 161(1): 91-96. http://www.jstor.org/stable/1514172.

Loebl, M, JEE van Beusekom, and K Reise. 2006. Is spread of the neophyte Spartina anglica recently enhanced by increasing temperatures? Aquatic Ecology 40(3): 315-324. https://doi.org/10.1007/ s10452-006-9029-3.

Maherali, H, AE Walden, and BC Husband. 2009. Genome duplication and the evolution of physiological responses to water stress. New Phytologist 184(3): 721-731. https://doi.org/10.1111/j.14698137.2009.02997.x.

Marburger, S, P Monnahan, PJ Seear, SH Martin, J Koch, P Paajanen, M Bohutínská, JD Higgins, R Schmickl, and L Yant. 2019. Interspecific introgression mediates adaptation to whole genome duplication. Nature Communications 10(1): 5218. https://doi.org/10.1038/s41467-019-13159-5.

Marchant, CJ. 1967. Evolution in Spartina (Gramineae): I. The history and morphology of the genus in Britain. Journal of the Linnean Society of London, Botany 60(381): 1-24. https://doi.org/10.1111/j.1095-8339.1967.tb00076.x.

Marchant, CJ. 1968. Evolution in Spartina (Gramineae): II. Chromosomes, basic relationships and the problem of $S . x$ townsendii agg. Journal of the Linnean Society of London, Botany 60(383): 381-409. https://doi.org/10.1111/j.1095-8339.1968.tb00096.x.

Marchant, DB, DE Soltis, and PS Soltis. 2016. Patterns of abiotic niche shifts in allopolyploids relative to their progenitors. New Phytologist 212(3): 708-718. https://doi.org/10.1111/nph.14069.

Maricle, BR, and RW Lee. 2007. Root respiration and oxygen flux in salt marsh grasses from different elevational zones. Marine Biology 151(2): 413-423. https://doi.org/10.1007/s00227-006-0493-z.

Marks, TC, and AJ Truscott. 1985. Variation in seed production and germination of Spartina anglica within a zoned saltmarsh. Journal of Ecology 73(2): 695-705. https://doi.org/10.2307/2260505.

McIntyre, PJ, and S Strauss. 2017. An experimental test of local adaptation among cytotypes within a polyploid complex. Evolution 71(8): 1960-1969. https://doi.org/10.1111/evo.13288.

Meeus, S, K Šemberová, N De Storme, D Geelen, and M VallejoMarín. 2020. Effect of whole-genome duplication on the evolutionary rescue of sterile hybrid monkeyflowers. Plant Communications 1(6): 100093. https://doi.org/10.1016/j.xplc.2020.100093.

Meimberg, H, KJ Rice, NF Milan, CC Njoku, and JK McKay. 2009. Multiple origins promote the ecological amplitude of allopolyploid Aegilops (Poaceae). American Journal of Botany 96(7): 1262-1273. https://doi.org/10.3732/ajb.0800345.

Mennema, J, AJ Quene-Boterenbrood, and CL Plate. 2013. Atlas of the Netherlands flora: extinct and very rare species. Netherlands: Springer.

Michaelis, H. 2008. Langzeitstudie zur Entwicklung von Höhenlage, Sediment, Vegetation und Bodenfauna in Landgewinnungsfeldern. Tech. rep., Niedersächsischer Landesbetrieb für 
Wasserwirtschaft, Küsten- und Naturschutz, Geschäftsbereich Gewässerbewirtschaftung und Flussgebietsmanagement; (Forschungstelle Küste, An der Mühle 5, 26548 Norderney, Germany).

Møller, J, LJ Wong, and S Pagad. 2018. Global Register of Introduced and Invasive Species - Denmark. https://doi.org/10.15468/1jbiia (visited on 10/27/2019).

Mudd, SM, A D'Alpaos, and JT Morris. 2010. How does vegetation affect sedimentation on tidal marshes? Investigating particle capture and hydrodynamic controls on biologically mediated sedimentation. Journal of Geophysical Research: Earth Surface 115(F3). https://doi.org/10.1029/2009JF001566.

Mueller, P, D Granse, S Nolte, M Weingartner, S Hoth, and K Jensen. 2020. Unrecognized controls on microbial functioning in Blue Carbon ecosystems: the role of mineral enzyme stabilization and allochthonous substrate supply. Ecology and Evolution 10(2): 998-1011. https://doi.org/10.1002/ece3.5962.

Mueller-Dombois, D, and H Ellenberg. 1974. Community Sampling: The Relevé Method. In Aims and methods of vegetation ecology, chap. 5, 45-66. New York: John Wiley; Sons.

Nehring, S, and HE Adsersen. 2006. NOBANIS - Invasive alien species fact sheet - Spartina anglica. Online Database of the North European and Baltic Network on Invasive Alien Species, Date of access 03/03/2019. https://www.nobanis.org.

Nehring, S, and KJ Hesse. 2008. Invasive alien plants in marine protected areas: the Spartina anglica affair in the European Wadden Sea. Biological Invasions 10(6): 937-950. https://doi.org/ 10.1007/s10530-008-9244-z.

Novikova, PY, N Hohmann, and Y Van de Peer. 2018. Polyploid Arabidopsis species originated around recent glaciation maxima. Current Opinion in Plant Biology 42: 8-15. https://doi.org/10.1016/ j.pbi.2018.01.005.

Oksanen, J, and PR Minchin. 2002. Non-linear maximum likelihood estimation of Beta and HOF response models. https://www.researchgate.net/publication/238659992_Non-linear_ maximum_likelihood_estimation_of_Beta_and_HOF_response_ models (visited on 09/02/2021).

Oost, AP, J Hofstede, R Weisse, F Baart, G Janssen, and R Zijlstra. 2017. Climate change. In Wadden Sea Quality Status Report 2017, eds. S. Kloepper, et al., 32. Wilhelmshaven: Common Wadden Sea Secretariat. Last updated 21.12.2017. https://qsr. waddensea-worldheritage.org/reports/climate-change (visited on 07/27/2019).

Partridge, TR. 1987. Spartina in New Zealand. New Zealand Journal of Botany 25(4): 567-575. https://doi.org/10.1080/0028825X. 1987.10410087.

Peterson, PM, K Romaschenko, YH Arrieta, and JM Saarela. 2014. A molecular phylogeny and new subgeneric classification of Sporobolus (Poaceae: Chloridoideae: Sporobolinae). TAXON 63(6): 1212-1243. https://doi.org/10.12705/636.19.

Peterson, R, J Slovin, and C Chen. 2010. A simplifed method for differential staining of aborted and non-aborted pollen grains. International Journal of Plant Biology 1(2). https://doi.org/10.4081/pb. 2010.e13.

Philippart, CJM, L Mekkes, C Buschbaum, KM Wegner, and K Laursen. 2017. Climate ecosystems. In Wadden Sea Quality Status Report 2017, eds. S. Kloepper, et al. Wilhelmshaven: Common Wadden Sea Secretariat. https://qsr.waddensea-worldheritage.org/ reports/climate-ecosystems (visited on 11/23/2018).

Piirainen, M. 2015. Pattern of morphological variation of Salicornia in north Europe. Nordic Journal of Botany 33(6): 733-746. https://doi.org/10.1111/njb.00848.

Proença, B, T Nez, A Poli, A Ciutat, L Devaux, A Sottolichio, X de Montaudouin, and R Michalet. 2019. Intraspecific facilitation explains the spread of the invasive engineer Spartina anglica in Atlantic salt marshes. Journal of Vegetation Science 30(2): 212-223. https://doi.org/10.1111/jvs.12720.

R Development Core Team. 2011. R: A Language and Environment for Statistical Computing. http://www.r-project.org.

Ramsey, J. 2011. Polyploidy and ecological adaptation in wild yarrow. PNAS 108(17): 7096-7101. https://doi.org/10.1073/pnas. 1016631108.

Ramsey, J, and DW Schemske. 2002. Neopolyploidy in flowering plants. Annual Review of Ecology and Systematics 33(1): 589-639. https://doi.org/10.1146/annurev.ecolsys.33.010802.150437.

Ranwell, DS. 1967. World Resources of Spartina townsendii (sensu lato) and Economic Use of Spartina Marshland. Journal of Applied Ecology 4(1): 239-256. https://doi.org/10.2307/2401421.

Raybould, A. 2005. History and ecology of Spartina anglica in Poole Harbour. In The Ecology of Poole Harbour, chap. 6, pp 71-90, eds. J. Humphreys, and V. May. Proceedings in Marine Science. Vol. 7. Amsterdam: Elsevier. https://doi.org/10.1016/S1568-2692(05)80011-7.

Renny-Byfield, S, M Ainouche, IJ Leitch, KY Lim, SC Le Comber, and AR Leitch. 2010. Flow cytometry and GISH reveal mixed ploidy populations and Spartina nonaploids with genomes of $S$. alterniflora and S. maritima origin. Annals of Botany 105(4): 527-533. http://www.jstor.org/stable/43576512.

Rice, A, P Šmarda, M Novosolov, M Drori, L Glick, N Sabath, S Meiri, J Belmaker, and I Mayrose. 2019. The global biogeography of polyploid plants. Nature Ecology and Evolution 3(2): 265-273. https://doi.org/10.1038/s41559-018-0787-9.

Saarela, JM. 2012. Taxonomic synopsis of invasive and native Spartina (Poaceae, Chloridoideae) in the Pacific Northwest (British Columbia, Washington and Oregon), including the first report of Spartina $\times$ townsendii for British Columbia, Canada. PhytoKeys 10: 25-82. https://doi.org/10.3897/phytokeys.10. 2734.

Schröder, HK, K Kiehl, and M Stock. 2002. Directional and nondirectional vegetation changes in a temperate salt marsh in relation to biotic and abiotic factors. Applied Vegetation Science 5(1): 33-44. https://doi.org/10.1111/j.1654-109X.2002.tb00533.x.

Segraves, KA, and TJ Anneberg. 2016. Species interactions and plant polyploidy. American Journal of Botany 103(7): 1326-1335. https://doi.org/10.3732/ajb.1500529.

Soltis, DE, CJ Visger, D Blaine Marchant, and PS Soltis. 2016. Polyploidy: Pitfalls and paths to a paradigm. American Journal of Botany 103(7): 1146-1166. https://doi.org/10.3732/ajb.1500501.

Soltis, PS, and DE Soltis. 2016. Ancient WGD events as drivers of key innovations in angiosperms. Current Opinion in Plant Biology 30: 159-165. https://doi.org/10.1016/j.pbi.2016.03.015.

Soltis, PS, X Liu, DB Marchant, CJ Visger, and DE Soltis. 2014. Polyploidy and novelty: Gottlieb's legacy. Philosophical Transactions of the Royal Society B: Biological Sciences 369(1648). https://doi.org/10.1098/rstb.2013.0351.

Sonnleitner, M, GM Schneeweiss, PE García, K Hülber, M Winkler, P Schönswetter, R Flatscher, and J Suda. 2015. Ecological differentiation of diploid and polyploid cytotypes of Senecio carniolicus sensu lato (Asteraceae) is stronger in areas of sympatry. Annals of Botany 117(2): 269-276. https://doi.org/10.1093/aob/mcv176.

Strain, EMA, J van Belzen, P Comandini, J Wong, TJ Bouma, and L Airoldi. 2017. The role of changing climate in driving the shift from perennial grasses to annual succulents in a Mediterranean saltmarsh. Journal of Ecology 105(5): 1374-1385. https://doi.org/10.1111/1365-2745.12799.

Suchrow, S, and K Jensen. 2010. Plant Species Responses to an Elevational Gradient in German North Sea Salt Marshes. Wetlands 30(4): 735-746. https://doi.org/10.1007/s13157-010-0073-3.

Suchrow, S, M Stock, and K Jensen. 2015. Patterns of Plant Species Richness Along Environmental Gradients in German 
North Sea Salt Marshes. Estuaries and Coasts 38(1): 296-309. https://doi.org/10.1007/s12237-014-9810-9.

Suda, J, and P Trávníček. 2006. Reliable DNA ploidy determination in dehydrated tissues of vascular plants by DAPI flow cytometrynew prospects for plant research. Cytometry Part A 69A(4): 273-280. https://doi.org/10.1002/cyto.a.20253.

te Beest, M, JJ Le Roux, DM Richardson, AK Brysting, J Suda, M Kubešová, and P Pyšek. 2012. The more the better? The role of polyploidy in facilitating plant invasions. Annals of Botany 109(1): 19-45. https://doi.org/10.1093/aob/mcr277.

Teege, P, JW Kadereit, and G Kadereit. 2011. Tetraploid European Salicornia species are best interpreted as ecotypes of multiple origin. Flora - Morphology, Distribution, Functional Ecology of Plants 206(10): 910-920. https://doi.org/10.1016/j.flora.2011.05. 009.

Theodoridis, S, C Randin, O Broennimann, T Patsiou, and E Conti. 2013. Divergent and narrower climatic niches characterize polyploid species of European primroses in Primula sect. Aleuritia. Journal of Biogeography 40(7): 1278-1289. https://doi.org/10.1111/jbi.12085.

Thijsse, JP. 1924. EEN NIEUW GRAS. DE LEVENDE NATUUR 29(8): 233-240.

Thompson, JD, T Mcneilly, and AJ Gay. 1991a. Population variation in Spartina anglica C. E. Hubbard I. Evidence from a common garden experiment. New Phytologist 117(1): 115-128. https://doi.org/10.1111/j.1469-8137.1991.tb00951.x.

Thompson, JD, T Mcneilly, and AJ Gray. 1991b. Population variation in Spartina anglica C. E. Hubbard II. Reciprocal transplants among three successional populations. New Phytologist 117(1): 129-139. https://doi.org/10.1111/j.1469-8137.1991.tb00952.x.

Tinoco, RO, and G Coco. 2018. Turbulence as the main driver of resuspension in oscillatory flow through vegetation. Journal of Geophysical Research: Earth Surface 123(5): 891-904. https://doi.org/10.1002/2017JF004504.

Vinther, N, C Christiansen, and J Bartholdy. 2001. Colonisation of Spartina on a tidal water divide, Danish Wadden Sea. Geografisk Tidsskrift-Danish Journal of Geography 101(1): 1119. https://doi.org/10.1080/00167223.2001.10649447.
Visser, V, and J Molofsky. 2015. Ecological niche differentiation of polyploidization is not supported by environmental differences among species in a cosmopolitan grass genus. American Journal of Botany 102(1): 36-49. https://doi.org/10.3732/ajb.1400432.

Wefferling, KM, S Castro, J Loureiro, M Castro, D Tavares, and SB Hoot. 2017. Cytogeography of the subalpine marsh marigold polyploid complex (Caltha leptosepala s.l., Ranunculaceae). American Journal of Botany 104(2): 271-285. https://doi.org/10.3732/ajb.1600365.

Wendel, JF. 2000. Genome evolution in polyploids. In: Plant Molecular Evolution, eds. J.J. Doyle, B.S. Gaut. Springer, Dordrecht. https://doi.org/10.1007/978-94-011-4221-2_12.

Widdows, J, ND Pope, and MD Brinsley. 2008. Effect of Spartina anglica stems on near-bed hydrodynamics, sediment erodability and morphological changes on an intertidal mudflat. Marine Ecology Progress Series 362: 45-57. http://www.jstor.org/stable/ 24872563.

Wiersma, AP, AP Oost, MW van der Berg, PC Vos, V Marges, and S de Vries. 2009. Geomorphology. Thematic Report No. 9. In Quality Status Report 2009. WaddenSea Ecosystem No. 25, eds. H. Marencic and J. de Vlas. Common Wadden Sea Secretariat, Trilateral Monitoring; Assessment Group, Germany: Wilhelmshaven.

Witte, S, H Freund, N Buhk, K Klement, T Schürmann, and L Giani. 2018. Impact of pedological conditions on the distribution of Salicornia species (Southern North Sea coast). Journal of Coastal Conservation 22(1): 79-85. https://doi.org/10.1007/s11852-0160487-z.

Wong, J, F Costantini, N Merloni, L Savelli, D Geelen, and L Airoldi. 2018. The widespread and overlooked replacement of Spartina maritima by non-indigenous $S$. anglica and $S$. townsendii in north-western Adriatic saltmarshes. Biological Invasions 20: 1687-1702. https://doi.org/10.1007/s10530-017-1654-3.

Publisher's note Springer Nature remains neutral with regard to jurisdictional claims in published maps and institutional affiliations. 